\title{
A Study on Precursors of Nitric Oxide in Sidestream Smoke*
}

\author{
by S. Umemura, M. Muramatsu and T. Okada \\ Central Research Institute, Japan Tobacco Inc., Yokobama, Japan
}

\section{SUMMARY}

By a method of thermal analysis and smoke analysis of cellulose cigarettes treated with various nitrogenous compounds, it was found that nitric oxide in sidestream smoke is formed not only from nitrates but also from amino acids and water-insoluble protein, while little of the nitric oxide in mainstream smoke is formed from these organic nitrogenous compounds.

\section{ZUSAMMENFASSUNG}

Mittels thermischer Analyse und Rauchanalyse wurde an Cellulosezigaretten, die mit verschiedenen Stickstoffverbindungen behandelt worden waren, festgestellt, daß im Nebenstromrauch enthaltenes Stickoxid nicht nur aus Nitraten, sondern auch aus Aminosäuren und aus in Wasser nicht löslichem Eiweiß entsteht, während das Stickoxid des Hauptstromrauches nur in geringem Maße von diesen organischen Stickstoffverbindungen herstammt.

\footnotetext{
* Received; 3rd January 1985 - accepted: 18th December 1985.
}

\section{RESUME}

Au moyen d'une méthode d'analyse thermique et d'une analyse de la fumée sur des cigarettes de cellulose ayant été traitées auparavant avec différents composés azotés, on a établi que le monoxyde d'azote contenu dans le flux de fumée secondaire est créé non seulement à partir des nitrates mais encore $a$ partir d'acides aminés et de protéines insolubles dans l'eau, tandis que l'oxyde d'azote présent dans le flux de fumée principal n'est formé qu'en faible quantité à partir de ces constituants organiques azotés.

\section{INTRODUCTION}

It is well known that a large portion of the nitrogen oxides in the mainstream smoke (MS) and sidestream smoke (SS) of cigarettes is nitric oxide (NO) $(1,2)$. Since the amount of NO in mainstream smoke is quantitatively related to the level of nitrate in tobacco (14), nitrate has been regarded as a major source of NO in mainstream smoke. On the other hand, it has been suggested that NO in sidestream smoke might be pro- 
duced from other sources besides nitrate $(1,4,5)$. Recently, NORMan et al. have demonstrated that there remained a significant amount of NO in both mainstream and sidestream smoke which could not have arisen from nitrate, and suggested that part of the residual NO probably arose from the oxidation of atmospheric nitrogen (4). In sidestream smoke, however, atmospheric nitrogen contributes to only part of the residual NO. Therefore, the nitrogen source of NO in sidestream smoke hąs not yet been completely clarified. In order to identify other nitrogen sources, our investigation was carried out by a method of thermal analysis and smoke analysis of cellulose cigarettes to which various nitrogen compounds were added.

\section{MATERIALS AND METHODS}

\section{Cigarette Samples}

Unblended non-filter cigarettes differing in nitrate content were prepared. Weight and nitrate content of the samples are shown in Table 1. Additionally, handmade cellulose cigarettes composed of filter paper shreds treated with $\mathrm{K}_{2} \mathrm{CO}_{3}$ as a burning additive were used. A given amount of various nitrogenous compounds such as potassium nitrate, asparagine, glutamic acid, proline and nicotine, or the water-insoluble residue of tobacco powder was added to the filter paper to examine the possibility of their acting as a source of NO in smoke. All cigarettes were $70 \mathrm{~mm}$ in length and $8 \mathrm{~mm}$ in diameter and were wrapped with ordinary cigarette paper with a permeability of $10 \mathrm{~cm}^{3} / \mathrm{min} / \mathrm{cm}^{2} / 10 \mathrm{~cm} \mathrm{H} \mathrm{H}_{2} \mathrm{O}$. The nitrate content was measured with a nitrate ion selective electrode ${ }^{*}$.

\footnotetext{
* Orion Research Inc., Cambridge, Mass. (Model 901).

** Monitor Labs. Inc., San Diego, Calif. (Model 8440).
}

Figure 1.

Schematic diagram of measurement of nitrogen oxides in clgarette smoke.

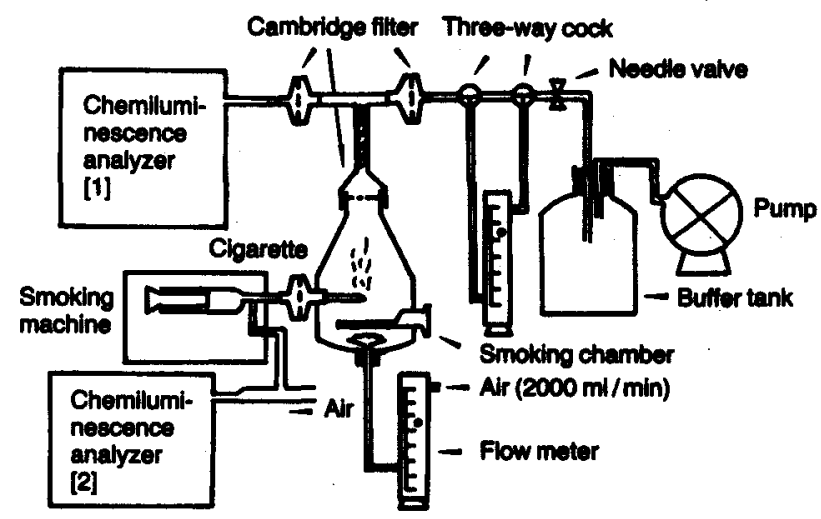

\section{Measurements of Nitrogen Oxides in Cigarette Smoke}

Figure 1 illustrates the scheme for the simultaneous measurement of $\mathrm{NO}$ and $\mathrm{NO}_{x}$ in the sidestream smoke (SS) and $\mathrm{NO}_{\mathbf{x}}$ in the mainstream smoke (MS) of cigarettes. Cigarettes were lit by electric heater and smoked to a $30 \mathrm{~mm}$ butt in a smoking chamber (volume: about $1000 \mathrm{ml}$ ) by means of a syringe-type smoking machine. The flow of air into the chamber was held constant at $2000 \mathrm{ml} / \mathrm{min}$, which was necessary to ensure the same number of puffs as under standard smoking conditions without the chamber, and to prevent sidestream smoke from accumulating in the chamber. The sidestream smoke diluted with air was passed through a Cambridge filter pad attached to the outlet end of the chamber to remove particulate matter. Part of the sidestream gas phase flowing out of the chamber was continuously passed through a chemiluminescence NO/ $\mathrm{NO}_{x}$ analyzer** at a constant sampling rate. On the

Table 1.

Amount of nitrogen oxides in unblended clgarette smoke.

\begin{tabular}{|c|c|c|c|c|c|c|c|c|}
\hline \multirow{3}{*}{ Cigarette } & & \multirow{3}{*}{$\begin{array}{c}\text { Nitrate } \\
\text { content } \\
\text { (dry basis) } \\
(\%)\end{array}$} & \multirow{3}{*}{$\begin{array}{c}\text { Cigarette } \\
\text { weight } \\
\text { (g) }\end{array}$} & \multirow{3}{*}{$\begin{array}{l}\text { Puff } \\
\text { count }\end{array}$} & \multicolumn{3}{|c|}{ Nitrogen oxides ( $\mu \mathrm{mol} / \mathrm{clgarette}$ ) } & \multirow{3}{*}{$\begin{array}{c}\text { SS/MS ratio } \\
\text { of NO }\end{array}$} \\
\hline & & & & & \multirow{2}{*}{$\begin{array}{c}\begin{array}{c}\text { Mainstream } \\
\text { smoke (MS) }\end{array} \\
\mathrm{NO}_{\mathrm{x}}\end{array}$} & \multicolumn{2}{|c|}{ Sidestream smoke (SS) } & \\
\hline & & & & & & NO & $\mathbf{N O}_{\mathbf{x}}$ & \\
\hline \multirow[t]{3}{*}{ Flue-cured } & A & 0.075 & 1.07 & 10.5 & 2.41 & 17.0 & 17.8 & 7.1 \\
\hline & B & 0.057 & 0.98 & 9.7 & 2.49 & 29.9 & 30.9 & 12.0 \\
\hline & c & 0.11 & 0.92 & 8.0 & 1.43 & 18.3 & 17.1 & 12.8 \\
\hline \multirow[t]{3}{*}{ Domestic } & $\mathbf{D}$ & 0.41 & 0.73 & 7.0 & 2.93 & 25.2 & 24.8 & 8.6 \\
\hline & $\mathbf{E}$ & 0.69 & 0.86 & 8.3 & 5.25 & 29.0 & 29.1 & 5.5 \\
\hline & $\mathbf{F}$ & 1.57 & 0.65 & 4.8 & 6.66 & 23.0 & 24.9 & 3.5 \\
\hline \multirow[t]{5}{*}{ Burley } & $\mathbf{G}$ & 0.58 & 0.79 & 6.5 & 3.79 & 21.2 & 21.5 & 5.6 \\
\hline & $H$ & 0.26 & 0.79 & 6.0 & 3.04 & 22.5 & 21.1 & 7.4 \\
\hline & 1 & 0.48 & 0.76 & 6.0 & 2.14 & 19.8 & 19.8 & 9.3 \\
\hline & $\mathbf{J}$ & 0.41 & 0.77 & 5.8 & 2.00 & 18.9 & 18.7 & 9.5 \\
\hline & $K$ & 3.32 & 0.81 & 5.3 & 17.50 & 65.2 & 66.5 & 3.7 \\
\hline
\end{tabular}


Figure 2.

Relationship between NO yleld of mainstream smoke and nitrate content in tobacco.

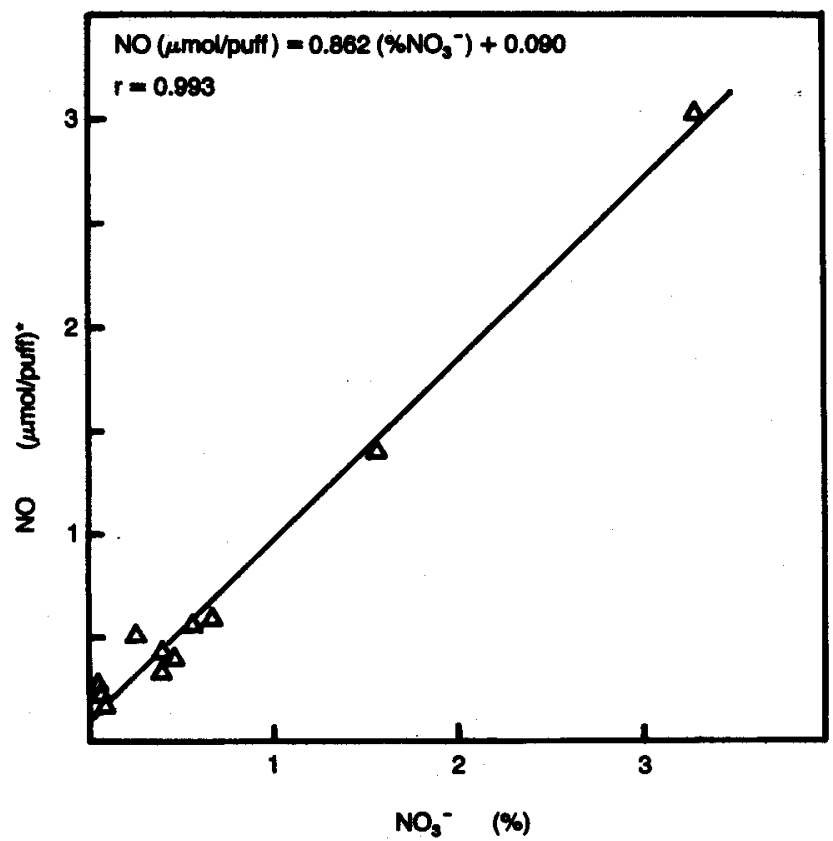

"The umol/puff values are obtained from the values as shown in Table 1.

other hand, individual puffs of mainstream smoke were passed through a Cambridge filter pad into the sampling stream (air: $1000 \mathrm{ml} / \mathrm{min}$ ) of a chemiluminescence $\mathrm{NO}_{x}$ analyzer ${ }^{+}$. NO and $\mathrm{NO}_{x}$ levels were determined from the output peak areas on the basis of a calibration curve.

It could be experimentally ascertained by this instrument that the measurement of $\mathrm{NO}_{\mathrm{x}}$ was only slightly interfered with by $\mathrm{CO}, \mathrm{CO}_{2}$ and nitrogen compounds, such as ammonia and hydrogen cyanide.

As shown in Table 1, no significant difference in the amounts of $\mathrm{NO}$ and $\mathrm{NO}_{x}$ could be observed in sidestream smoke. Therefore, nitric oxide in sidestream smoke was determined in the condition of NO mode. As for the mainstream smoke, little difference in the values determined was observed between $\mathrm{NO}_{x}$ and NO mode in the $\mathrm{NO} / \mathrm{NO}_{x}$ analyzer, which agreed with the findings by other workers $(2,6)$. Hence, hereafter $\mathrm{NO}_{x}$ in mainstream smoke will be referred to as NO.

\section{Formation Profile of NO}

Temperature-yield profiles of NO and weight loss (derivative thermogravimetry (DTG)) during the thermal decomposition of tobacco and cellulose containing various nitrogenous compounds were measured simultaneously to elucidate the process by which NO is

\footnotetext{
+ Yanaco (Model E11-77).

++ Rigaku Denki Co. (Model TG-DSC-8085D1).

** Monitor Labs. Inc., San Diego, Calif. (Model 8440).
}

Flgure 3.

Relationship between NO yleld of sidestream smoke and nitrate content in tobecco.

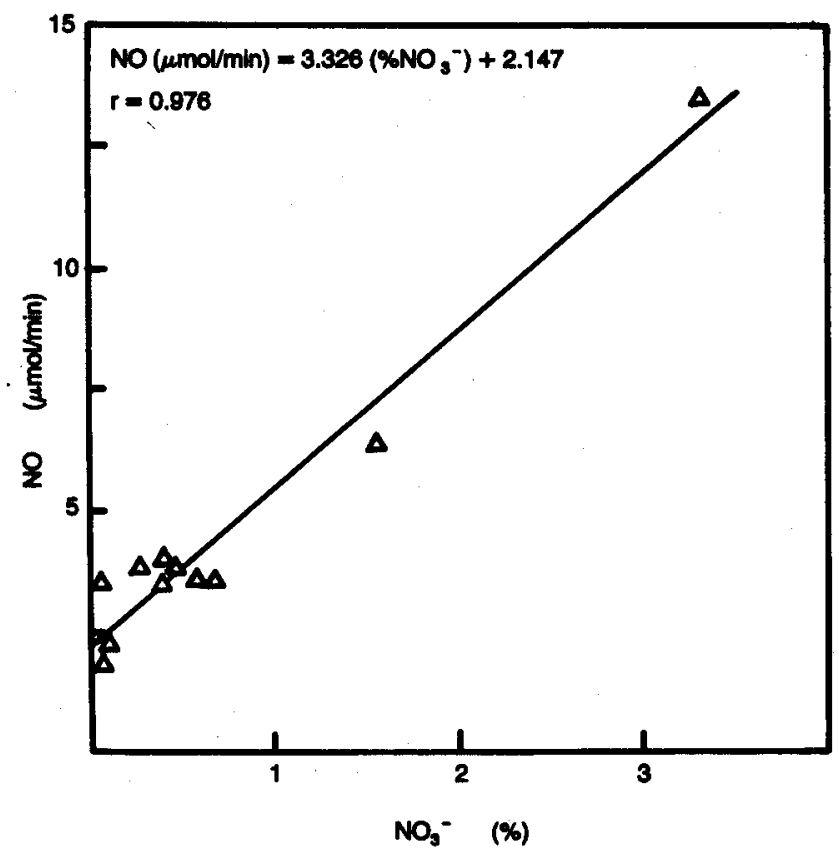

formed. With a thermobalance ${ }^{++}$, about $10 \mathrm{mg}$ of a ground sample were heated at a constant heating rate of $5^{\circ} \mathrm{C} / \mathrm{min}$ in an atmosphere of air or helium with a flow rate of $100 \mathrm{ml} / \mathrm{min}$. After removal of particulate matter with a Cambridge filter pad, the resulting gas was passed continuously through the sampling stream of a chemiluminescence $\mathrm{NO} / \mathrm{NO}_{x}$ analyzer ${ }^{* *}$ at the rate of $500 \mathrm{ml} / \mathrm{min}$ for analysis.

\section{RESULTS AND DISCUSSION}

\section{Nitrogen Oxides in \\ Mainstream and Sidestream Smoke of Unblended Cigarettes}

As shown in Table 1, the ratio of the NO level in sidestream smoke to that in mainstream smoke (SS/MS ratio) was in the range 3.5 to 12.8 . This ratio is significantly higher than that of the weight of tobacco consumed between puffs to that during puffs, reported in the range 1.1 to $3.6(7-9)$. This indicates that the rate of NO formation (the ratio of NO yield formed to the amount of tobacco consumed) between puffs is higher than that during a puff.

Figures 2 and 3 show mainstream NO yield per puff and sidestream NO yield per unit time as a function of the nitrate content in tobacco. These plots show that both mainstream NO yield per puff and sidestream NO yield per unit time are linearly related to nitrate content. In Figures 2 and 3 the extension of the line back to zero yields a value of $0.09 \mu \mathrm{mol} / \mathrm{puff}$ for main- 
Figure 4.

Typlcal temperature-yleld proflles for NO and weight loss (derlvatlve thermogravimetry (DTG)) curves of tobacco (domeatic tobacco: F).

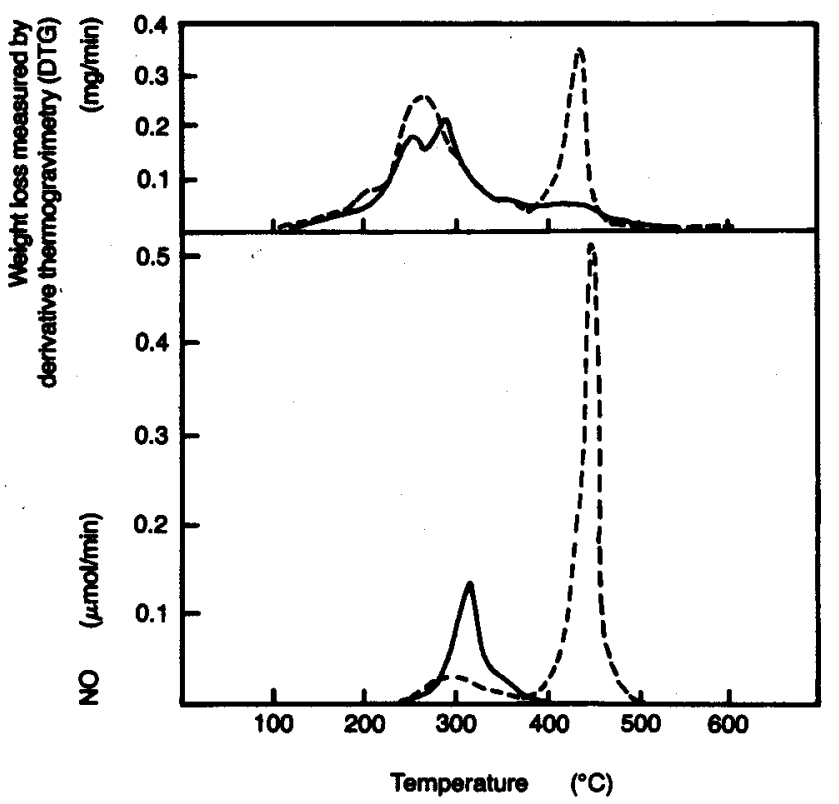

Sample weight: $10 \mathrm{mg}$. Heating rate: $5^{\circ} \mathrm{C} / \mathrm{min}$.

$$
- \text { : in helium }
$$

stream smoke and $2.15 \mu \mathrm{mol} / \mathrm{min}$ for sidestream smoke. This suggests that a certain amount of NO is formed from nitrogen sources other than nitrate, particularly for NO in sidestream smoke.

Figure 6.

Influence of nitrate content on the amount of NO evolved from tobacco heated at $5{ }^{\circ} \mathrm{C} / \mathrm{m} / \mathrm{n}$ in air atmosphere.

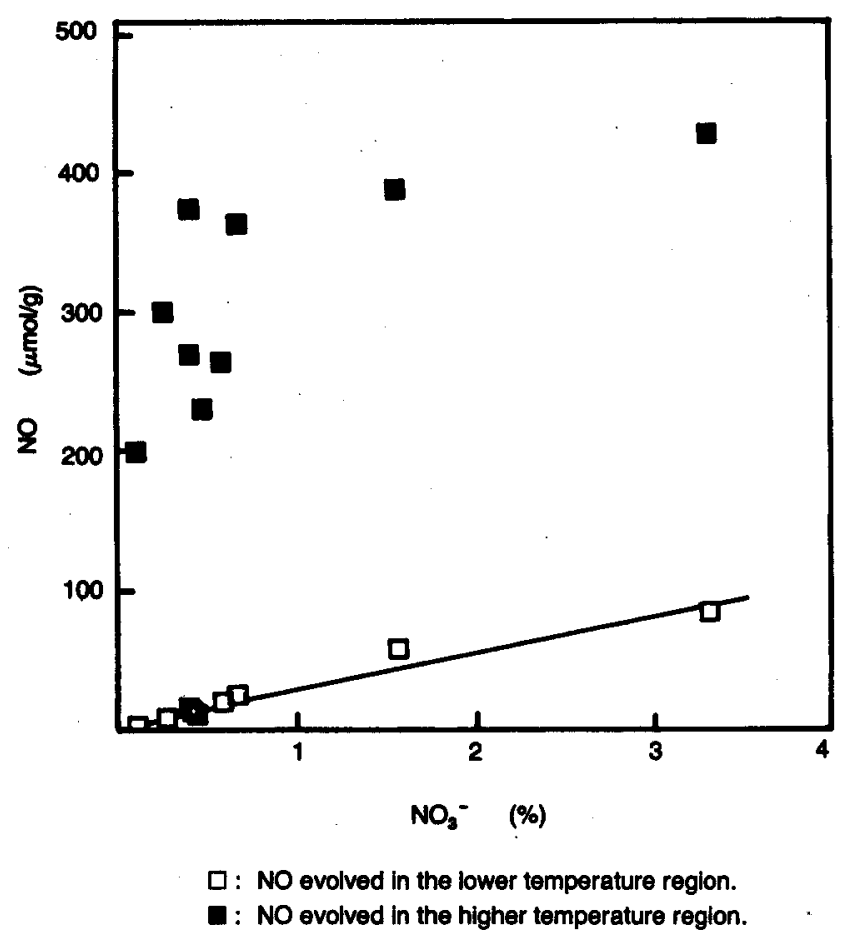

Figure 5.

Influence of nitrate content on the amount of NO evolved from tobacco heated at $5{ }^{\circ} \mathrm{C} / \mathrm{m} / \mathrm{n}$ in hellum atmosphere.

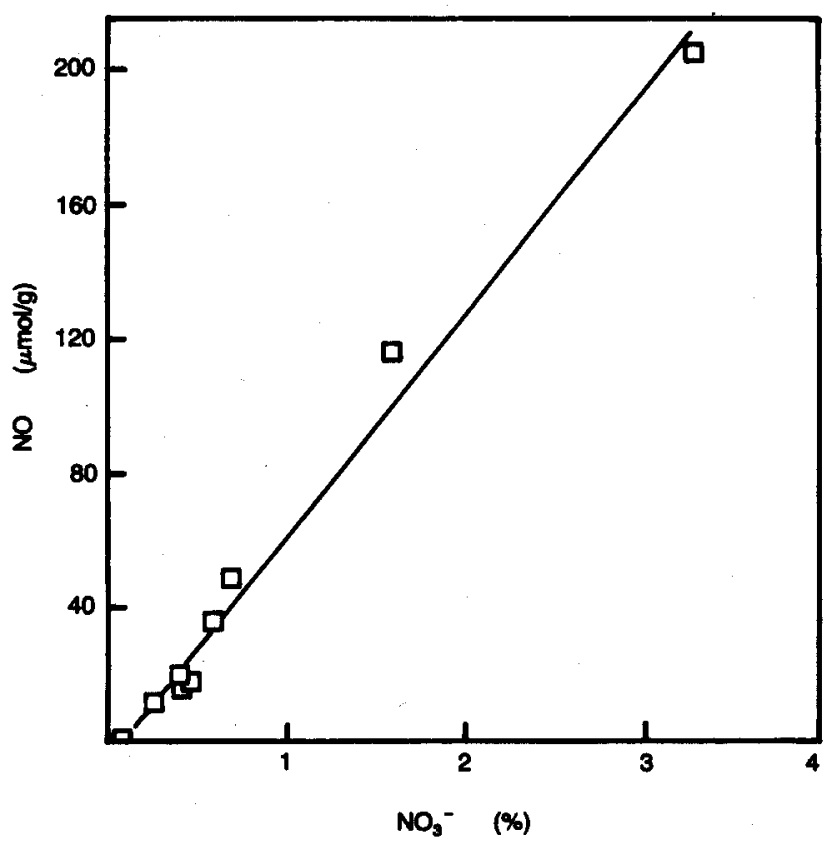

Formation Profiles of Nitric Oxide by Thermal Analysis

Figure 4 illustrates temperature-yield profiles for NO and weight loss (derivative thermogravimetry (DTG)) curves obtained by heating tobacco at $5{ }^{\circ} \mathrm{C} / \mathrm{min}$ in an atmosphere of air or helium with a flow rate of $1000 \mathrm{ml} / \mathrm{min}$. In the helium atmosphere, NO was produced in the temperature range of about $210-400^{\circ} \mathrm{C}$, showing a peak at about $315^{\circ} \mathrm{C}$. This temperature range approximately coincides with that of the rapid weight loss of tobacco due to thermal decomposition $(10,11)$. The amount of NO formed in this region is related to the nitrate content of the tobacco as shown in Figure 5. It is reasonable to conclude that in such an inert atmosphere NO is formed by the thermal decomposition of nitrate in the tobacco. In an atmosphere of air, NO was formed in the two temperature regions of $210-360^{\circ} \mathrm{C}$ and $360-550^{\circ} \mathrm{C}$ as shown in Figure 4. The lower temperature region corresponds to the thermal decomposition of the tobacco. The amount of NO formed in this region is dependent on the nitrate content as shown in Figure 6. On the other hand, a large amount of NO was produced in the higher temperature region, where carbonaceous residue left after the thermal decomposition of the tobacco was oxidized leaving ash $(11,12)$. As can be seen in Figure 6, the amount of NO formed in this region was independent of the nitrate content of the tobacco. These results imply that a considerable amount of NO can be formed by the oxidation of nitrogen sources other than nitrate in the presence of oxygen. To clarify this point, cellulose powders to which various organic nitrogen compounds 
had been added and, in addition, water-insoluble tobacco residue were subjected to EGA (evolved gas analysis) and weight loss (derivative thermogravimetry (DTG)) analysis. The results are shown in Figure 7. From the potassium nitrate added to cellulose, a considerable amount of $\mathrm{NO}$ was produced in both air and helium atmospheres (Figure 7 ( $a$ and $b$ )). The temperature region of $\mathrm{NO}$ formation showing a peak at about $350^{\circ} \mathrm{C}$ closely corresponds to the region of major weight loss of cellulose due to thermal decomposition $(10,11)$. In an air atmosphere, however, the region of NO formation shifts to lower temperatures showing a peak at about $310^{\circ} \mathrm{C}$. From the cellulose containing proline, glutamic acid or asparagine, NO was produced only in the presence of oxygen (Figure $7(c, d$ and $e)$ ). The production of NO from these amino acids occurs over a wide temperature range $\left(400-600^{\circ} \mathrm{C}\right)$. Since the thermal decomposition temperature of these amino acids is much lower than $400^{\circ} \mathrm{C}(13)$, the formation of NO from these amino acids seems to be caused by the oxidation of nitrogen-containing substances left after the complicated thermal reactions of the amino acids. Formation of NO from nicotine added to the cellulose was not observed even in an oxygen-containing atmosphere. Figure 8 shows NO temperature-yield profile and weight loss (derivative thermogravimetry (DTG)) curve for the water-insoluble residue prepared from Burley tobacco. The water-insoluble residue is free from nitrates and contains water-insoluble introgen compounds such as proteins. The production of NO from the residue was observed only in the presence of oxygen in the temperature region of $360-530^{\circ} \mathrm{C}$, showing a peak at $468^{\circ} \mathrm{C}$ and having a profile similar to those obtained for amino acids. The conversion efficiencies of nitrogen into NO obtained from the temperature-yield profiles shown in Figures 7 and 8, are summarized in Table 2. The conversion efficiencies of amino acids and water-insoluble nitrogen compounds were lower than that of nitrate.

\section{Nitric Oxide Formation in Cellulose Cigarettes}

Table 3 shows nitric oxide formation from cellulose cigarettes to which were added various organic nitrogen compounds. An appreciable amount of NO was found in both mainstream and sidestream smoke of cellulose cigarettes, even when nitrogen free. These values correspond to $0.09 \mu \mathrm{mol} /$ puff for mainstream smoke and $0.30 \mu \mathrm{mol} / \mathrm{min}$ for sidestream smoke. The NO yield per puff in the mainstream smoke was the same as that obtained from extension of the calculated values to zero nitrate (Figure 2). It seems to be caused by the oxidation of atmospheric nitrogen, as suggested by NoRmaN et al. (4). However, the NO yield per unit burning time in the sidestream smoke from the pure cellulose cigarette was no more than one seventh of that obtained from tobacco cigarettes as shown by the extrapolation back to zero in Figure 3. This suggests that the NO in sidestream smoke is formed by a process other than thermal decomposition of nitrate and/or oxidation of atmospheric nitrogen.

The addition of potassium nitrate to cellulose cigarettes enhanced the formation of NO in both mainstream and sidestream smoke, while nicotine hardly contributed to NO formation of either smoke stream. The addition of amino acids and nitrate-free water-insoluble residue of tobacco increased the NO yield of sidestream smoke significantly, but it had no noticeable effect on the NO yield of mainstream smoke. From the results and thermal analysis, it can be assumed that NO in sidestream smoke was formed not only by thermal decomposition of nitrate but also by oxidation of organic nitrogenous compounds such as amino acids and proteins.

BAKER and co-workers have reported on the difference in the contours of oxygen concentration in the burning coal for a puff and for static smouldering, indicating an oxygen deficiency in the interior region during a puff $(14-17)$. In addition, it has been reported by Jornson that incorporation of atmospheric oxygen into the var-

Table 2.

Conversion of nitrogen sources into NO when heated at the rate of $5^{\circ} \mathrm{C} / \mathrm{min}$.

\begin{tabular}{|c|c|c|c|c|}
\hline Samples* & Atmosphere & $\begin{array}{c}\text { Nitrogen content } \\
(\%)\end{array}$ & $\begin{array}{l}\text { Amount of NO } \\
(\mu \mathrm{mol} / \mathrm{g})\end{array}$ & $\begin{array}{c}\text { Conversion efficiency } \\
\qquad(\%)\end{array}$ \\
\hline $2.9 \% \mathrm{KNO}_{3}+$ cellulose & $\begin{array}{l}\text { hellum } \\
\text { air }\end{array}$ & 0.406 & $\begin{array}{l}112.8 \\
118.0\end{array}$ & $\begin{array}{l}39.0 \\
40.0\end{array}$ \\
\hline $2.7 \%$ asparagine + cellulose & air & 0.506 & 25.6 & 7.1 \\
\hline $4.5 \%$ glutamic acid + cellulose & air & 0.432 & 22.4 & 7.2 \\
\hline $4.2 \%$ proline + cellulose & air & 0.516 & 51.0 & 14.0 \\
\hline $\int(A)$ & air & 2.08 & 127.0 & 8.5 \\
\hline Water-extracted residue $\left\{\begin{array}{l}\text { (F) } \\
(G)\end{array}\right.$ & $\begin{array}{l}\text { air } \\
\text { air }\end{array}$ & $\begin{array}{l}2.58 \\
1.82\end{array}$ & $\begin{array}{l}199.0 \\
115.2\end{array}$ & $\begin{array}{r}11: 0 \\
8.9\end{array}$ \\
\hline
\end{tabular}

* Percentages of compound added to the actual weight basis of cellulose.

** (NO evolved/nitrogen added) $\times 100$. 
Figure 7.

Temperature-yield proflles for NO and welght loss (derlvative thermogravimetry (DTG)) curves of varlous nitrogenous compounds.

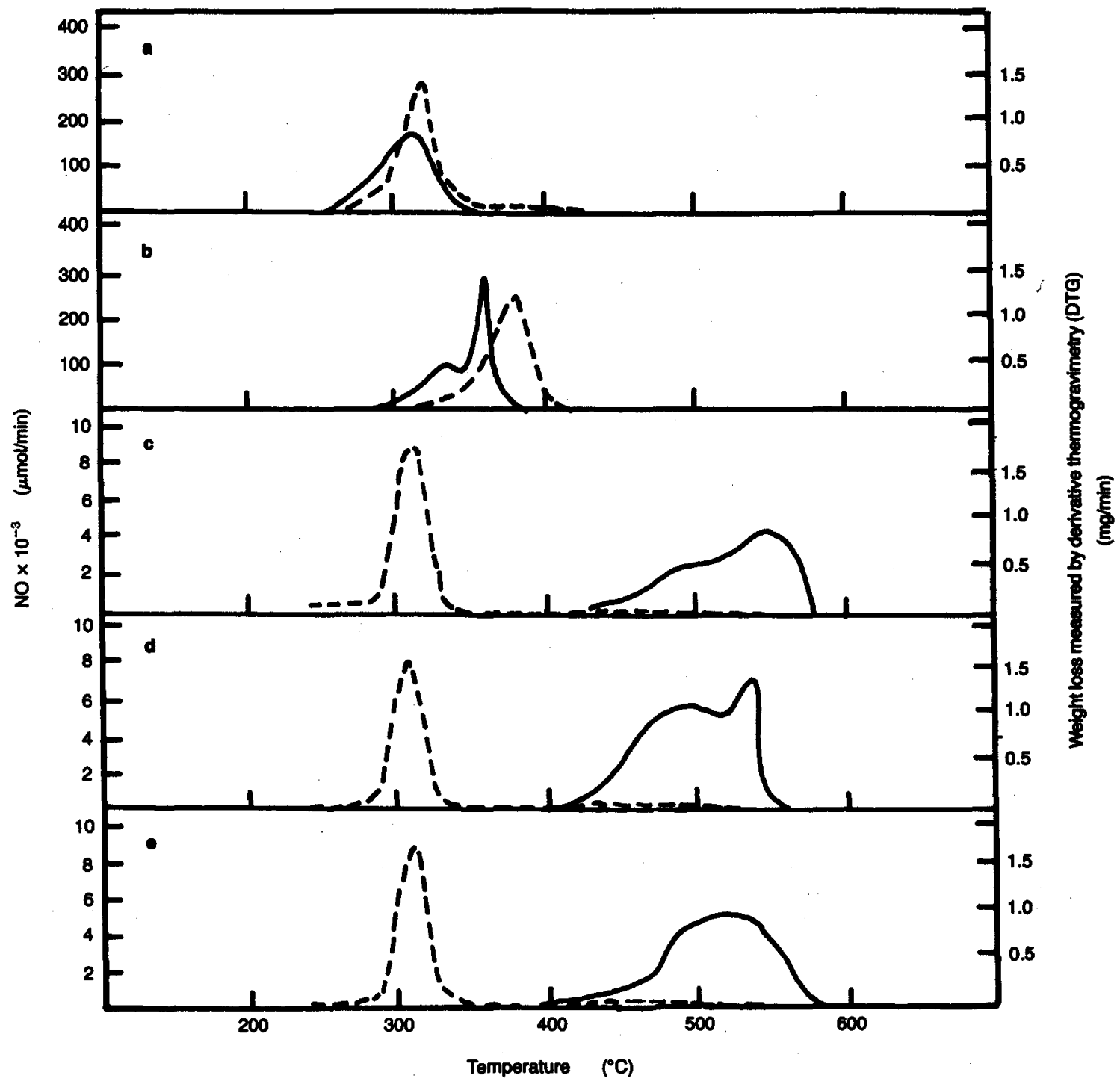

a: $2.9 \% \mathrm{KNO}_{3}+$ cellulose (in air).

b: $2.9 \% \mathrm{KNO}_{3}+$ cellulose (in hellum).

c: $2.7 \%$ asparagine + cellulose (in air)

d: $4.5 \%$ glutamic acid + cellulose (in air).

e: $4.2 \%$ proline + cellulose (in air).

Sample weight: $10 \mathrm{mg}$.

Heating rate: $5^{\circ} \mathrm{C} / \mathrm{min}$. 
Figure 8.

Temperature-yield profile for NO and welght loss (derlvative thermogravimetry (DTG)) curve of nitrate-free water-extracted realdue of tobacco (Burley: $\mathrm{G}$ ).

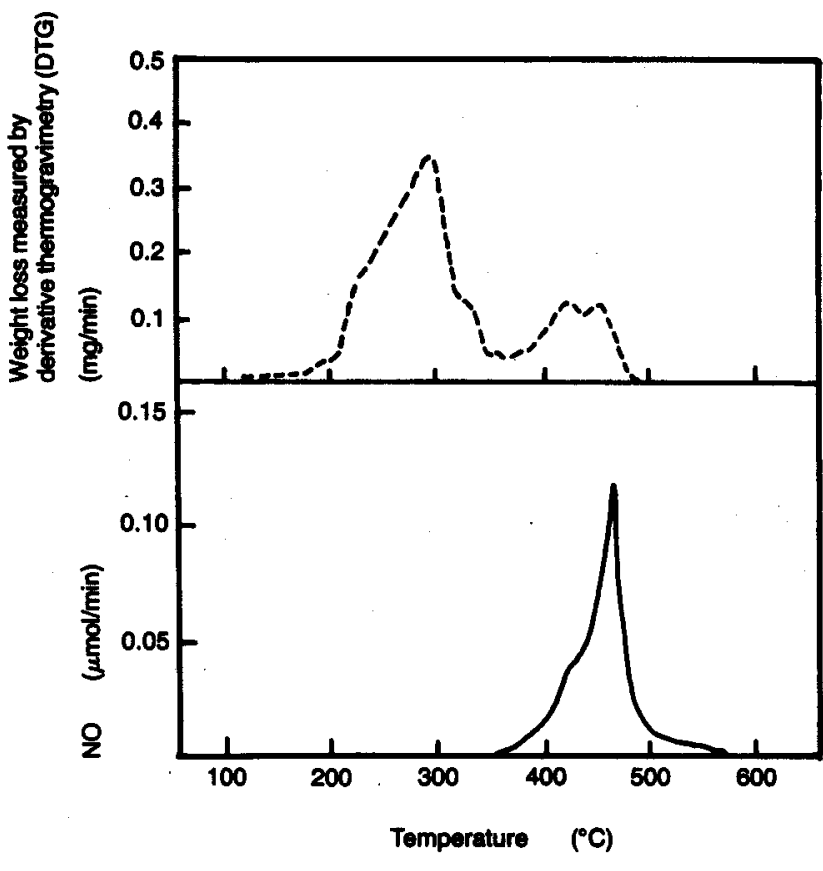

Sample weight: $10 \mathrm{mg}$. Heating rate: $5^{\circ} \mathrm{C} / \mathrm{min}$.

ious components of sidestream smoke was higher than that into the components of mainstream smoke (18). From these facts, it seems reasonable to conclude that a considerable amount of the NO in sidestream smoke is formed by the oxidation of organic nitrogenous compounds. This also explains the high SS/MS NO ratio observed for cigarettes with a low nitrate content as shown in Table 1.

\section{REFERENCES}

1. Hardy, D. R., and M. E. Hobbs: The use of ${ }^{15} \mathrm{~N}$ and of ${ }^{15} \mathrm{~N}$ and ${ }^{16} \mathrm{O}$ in added nitrates for the study of some generated constituents of normal cigarette smoke; Proc. Am. Chem. Soc. Symp. on Recent advances in the chemical composition of tobacco and tobacco smoke, 173rd Am. Chem. Soc. (Agric. Food Chem. Div.) meeting, New Orleans, Louisiana, 1977, 489-510.

2. Williams, T. B.: The determination of nitric oxide in gas phase cigarette smoke by non-dispersive infrared analysis; Beitr. Tabakforsch. Int. 10 (1980) 91-99.

3. Johnson, W. R., R. W. Hale, S. C. Clough and P. H. Chen: Chemistry of the conversion of nitrate nitrogen to smoke products; Nature (Lond.) 243 (1973) 223-225.

4. Norman, V., A. M. Ihrig, T. M. Larson and B. L. Moss: The effect of some nitrogenous blend components on $\mathrm{NO} / \mathrm{NO}_{x}$ and $\mathrm{HCN}$ levels in mainstream and sidestream smoke; Beitr. Tabakforsch. Int. 12 (1983) 55-62.

5. Klus, $H$., and $H$. Kuhn: Verteilung verschiedener Tabakrauchbestandteile auf Haupt- und Nebenstromrauch (Eine Übersicht); Beitr. Tabakforsch. Int. 11 (1982) 229-265.

6. Ogata, N., and A. Fukazawa: Determination of nitrate by ion selective electrode; Jpn. Monop. Corp. Cent. Res. Inst. Sci. Pap. 116 (1974) 71-74.

Table 3.

Yleld of nitric oxlde from cellulose clgarettes containing nitrogen compounds added.

\begin{tabular}{|c|c|c|c|c|c|}
\hline \multirow{2}{*}{$\begin{array}{l}\text { Additives added to } \\
\text { cellulose cigarette * }\end{array}$} & \multirow{2}{*}{$\begin{array}{c}\text { Nitrogen } \\
\text { content } \\
(\%)\end{array}$} & \multirow{2}{*}{$\begin{array}{c}\text { Cigarette } \\
\text { weight } \\
\text { (g) }\end{array}$} & \multirow{2}{*}{$\begin{array}{l}\text { Puff } \\
\text { count }\end{array}$} & \multicolumn{2}{|c|}{ Nitric oxide ( $\mu$ mol/cigarette) } \\
\hline & & & & $\begin{array}{l}\text { Mainstream } \\
\text { smoke (MS) }\end{array}$ & Sidestream smoke (SS) \\
\hline Nitrogen free & 0 & 0.56 & 3 & 0.29 & 0.91 \\
\hline $1.2 \% \mathrm{KNO}_{3}$ & 0.17 & 0.74 & 5 & 4.22 & 8.92 \\
\hline $2.0 \%$ asparagine & 0.42 & 0.62 & 4 & 0.05 & 3.38 \\
\hline $4.0 \%$ glutamic acid & 0.38 & 0.62 & 4 & 0.13 & 3.58 \\
\hline $3.4 \%$ proline & 0.41 & 0.56 & 4 & 0.10 & 2.31 \\
\hline $3.7 \%$ nicotine & 0.63 & 0.63 & 3 & 0.02 & 0.52 \\
\hline $\begin{array}{l}37 \% \text { water-extracted residue } \\
\text { (flue-cured) }\end{array}$ & 0.77 & 0.90 & 5.4 & 0.08 & 5.09 \\
\hline $\begin{array}{l}36 \% \text { water-extracted residue } \\
\text { (domestic) }\end{array}$ & 0.92 & 0.90 & 6 & 0.08 & 10.82 \\
\hline $\begin{array}{l}36 \% \text { water-extracted residue } \\
\text { (Burley) }\end{array}$ & 0.66 & 0.90 & 5.6 & 0 & 5.72 \\
\hline
\end{tabular}

" Percentages of compound added to the actual weight basis of cellulose. 
7. Johnson, W. R., R. W. Hale, J. W. Nedlock, H. J. Grubbs and D. H. Powell: The distribution of products between mainstream and sidestream smoke; Tob. Sci. 17 (1973) 141-144.

8. Okada, T., K. Ohta and Y. Masuo: A study of the burning rate of cigarettes between puffs; Paper presented at the 31st 'Tobacco Chemists' Research Conference, Greensboro, North Carolina, 1977.

9. Yamamoto, T., U. Anzai and T. Okada: Effect of cigarette circumference on weight loss during puffs and total delivery of tar and nicotine; Beitr. Tabakforsch. Int. 12 (1984) 259-269.

10. Muramatsu, M., S. Umemura, K. Ohta and T. Okada: Thermal analysis of tobacco on a viewpoint of kinetic approach; Netsusokutei 6 (1979) 137-145.

11. Muramatsu, M.: Studies on transport phenomena in naturally smouldering cigarettes; Jpn. Monop. Corp. Cent. Res. Inst. Sci. Pap. 123 (1981) 9-78.

12. Muramatsu, M., and S. Umemura: Kinetics of oxidation of tobacco char; Beitr. Tabakforsch. Int. 11 (1981) 79-86.

13. Seto, J.: Study on amino acids by using a thermobalance; Japan Analyst 9 (1960) 939-945.

14. Baker, R. R.: Environmental conditions inside a burning cigarette; in: Analytical calorimetry, Vol. 4, edited by R. S. Porter and J. F. Johnson, Plenum Publishing Corporation, New York, N.Y., 1977, pp. 193-202.
15. Baker, R. R., and K. D. Kilburn: The distribution of gases within the combustion coal of a cigarette; Beitr. Tabakforsch. 7 (1973) 79-87.

16. Baker, R. R.: Combustion and thermal decomposition regions inside a burning cigarette; Combust. Flame (Lond.) 30 (1977) 21-32.

17. Baker, R. R.: Mechanisms of smoke formation and delivery; Recent Adv. Tob. Sci. 6 (1980) 184-224.

18. Johnson, W. R.: Mechanism of smoke formation; Proc. Am. Chem. Soc. Symp. on Recent advances in the chemical composition of tobacco and tobacco smoke, 173rd Am. Chem. Soc. (Agric. Food Chem. Div.) meeting, New Orleans, Louisiana, 1977, 471-488.

Authors' address:

Central Research Institute,

Japan Tobacco Inc., 6-2 Umegaoka, Midori-kw, Yokobama, Kanagawa, 227, Japan. 